УДК 666.75

DOI https://doi.org/10.32838/2663-5941/2020.4/25

Казимиренко Ю.О.

Національний університет кораблебудування імені адмірала Макарова

Дрозд О.В.

Національний університет кораблебудування імені адмірала Макарова

Жарський $\boldsymbol{C . B .}$

Національний університет кораблебудування імені адмірала Макарова

\title{
ТЕХНОЛОГІЧНІ ОСОБЛИВОСТІ І ФІЗИКО-ХІМІЧНІ ПРОЦЕСИ ПЕРЕРОБКИ КРИШТАЛЕВОГО СКЛА НА ПОРОШОК
}

Стаття присвячена вирішенню актуальної на сьогоднішній час науково-практичної проблеми переробки скляного бою та бракованих скляних виробів з нарійсилікатного скла, різновидів кришталю, натрій-кальиій-силікатного скла, якими насичений сучасний ринок. Перспективним напрямом хімічних технологій є одержання скляних порошків. Описано експериментальні роботи та лабораторні дослідження щодо визначення хімічного складу, структури, властивостей, для чого застосовано методи оптичної і електронної мікроскопї, рентгеноструктурного аналізу; аналітичні розрахунки кінетики високотемпературних проиесів. Одержані результати зіставлено з діаграмами стану $\mathrm{PbO}-\mathrm{SiO}_{2}$, $\mathrm{Na}_{2} \mathrm{O}-\mathrm{CaO}-\mathrm{SiO}_{2}, \mathrm{Na}_{2} \mathrm{O}-\mathrm{SiO}_{2}$. Прочес розм'якшення досліджено за усадочними процесами, для чого застосовано авторський зразок лабораторної установки для виготовлення порошкових виробів.

Авторами пропонується технологічна схема переробки бою скла та бракованих кришталевих виробів на склопорошок, яка включатиме у себе операџї дроблення на дробариі до крупності до 10 мм з подальшим здрібненням до дисперсності $30 \ldots 80$ мкм у кульовому млині барабанного типу, виготовлення порошкової суміші з наступним ї̈ топленням при температурі $800{ }^{\circ} \mathrm{C}$ у муфельній печі з окиснювальним середовищем, дробленням та здрібненням спеченого агломерату. Встановлено, щьо одержані порошки є рентгеноаморфними, мають округлу форму; ї гранулометричний склад належить діапазону 40...70 мкм, їх мікротвердість становить близько 1,4 ГПа. Проаналізовано фізико-хімічні прочеси, характерні для кожного з етапів технологічного ииклу. Наведено теоретичне обгрунтування температурних режимів та результати мікроструктурних досліджень, морфологічних характеристик одержаних порошків. Експериментально визначена і теоретично обтрунтована важливість прочесу топлення скляного агломерату в діапазоні температур $300 \ldots 800{ }^{\circ} \mathrm{C}$ з максимальною інтенсивністю у перші 8-10 хв. Запропоновано перспективи їх подальшого застосування для виготовлення нових функціональних композиційних матеріалів і покриттів зі стабільними експлуатаційними властивостями.

Ключові слова: переробка, технологія, кришталеве скло, скляний бій, браковане скло, склопорочок, фізико-хімічні процеси.

Постановка проблеми. Браковані скляні вироби і скляний бій являють собою невіддільний складник виробництва і побуту, що потребує утилізації. В Україні розвиток сучасних переробних технологій обмежується через великі енергетичні витрати та складність обладнання. Сучасні принципи утилізації скляного боя грунтуються на унікальності хімічного складу і властивостей як «аморфного силікатного матеріалу антропогенного походження» [1].

Аналіз останніх досліджень і публікацій. На цей час скляний бій використовується в технологіях виготовлення листового скла, скляної тари, піноскла для тепло- і шумоізоляції, під час виробництва композиційних бетонів, покривних матері- алів, плиток для підлоги тощо [2-4]. Таким чином, виробництво композиційних матеріалів являе собою галузь, для якої скляні відходи та бій $є$ важливою вихідною сировиною, застосування якої сприятиме формуванню комплексу цінних властивостей, які не є характерними для будь-яких природних матеріалів або компактних металів. Для більшості технологій виробництва композиційних матеріалів, зокрема будівельних, не існує жорстких вимог за хімічним складом, які висуваються до хіміко-лабораторного, рентгенозахисного та інших видів скла за спеціальним призначенням [5]. Найвищими показниками хімічної чистоти характеризується кришталеве скло, з якого виробляється високоякісний посуд, декоративні вироби, предмети 
мистецтва [6; 7]. Крім декоративних властивостей, спеціалізоване посудне скло характеризуються термічною та хімічною стійкістю, механічною міцністю, твердістю. Його хімічний склад та технічні умови щодо виготовлення регламентовані ГОСТ 24315-80 і ГОСТ 30407-96. Сучасний ринок насичений різноманітними виробами, виготовленими 3: натрій-силікатного скла; різновидів кришталю, до складу яких входять двоокис кремнію $\left(\mathrm{SiO}_{2}\right)$, $\mathrm{Pb}, \mathrm{Ba} \mathrm{i} \mathrm{Zn}$, вміст яких у сумі складатиме не менш $10 \%$; спеціального натрій-кальцій-силікатного скла 3 функціональними додатками задля формування заданих фізико-механічних властивостей. 3 такого скла виготовляються масивні вироби у вигляді скульптур малих форм, ваз, попільниць тощо.

На кожному виробництві під час контролю якості виявляються дефекти, які негативно впливають на різні показники та властивості виробів: це дефекти скломаси, виробітки, обробки [8]. Таким чином, відбраковані вироби та скляний бій, який утворюється протягом виробничого циклу, пакування, транспортування, являє собою вторинну сировину 3 високою ліквідністю, переробка якого $\epsilon$ важливою науково-прикладною проблемою, вирішення якої спрямовано на скорочення виробничих відходів та розвиток нових технологій створення нових поліфункціональних матеріалів. Перспективним напрямом хімічних технологій є одержання скляних порошків [9].

Постановка завдання. Мета роботи полягає у дослідженні фізико-хімічних процесів і технологічних особливостей переробки кришталевого скла на порошок.

Виклад основного матеріалу. Експериментальні роботи включали у себе виготовлення порошку за технологічною схемою (рис. 1), для чого застосовано скляний бій та уламки різних видів кришталевих виробів.

Технологічна послідовність включатиме у себе: дроблення на дробарці до крупності до 10 мм 3 подальшим здрібненням до дисперсності $30 . .80$ мкм у кульовому млині барабанного типу; виготовлення порошкової суміші з наступним іiі топленням при температурі $800^{\circ} \mathrm{C}$ у муфельній печі з окиснювальним середовищем, дробленням та здрібненням спеченого агломерату. Технологічні режими, застосоване обладнання та пристосування наведено у табл. 1.

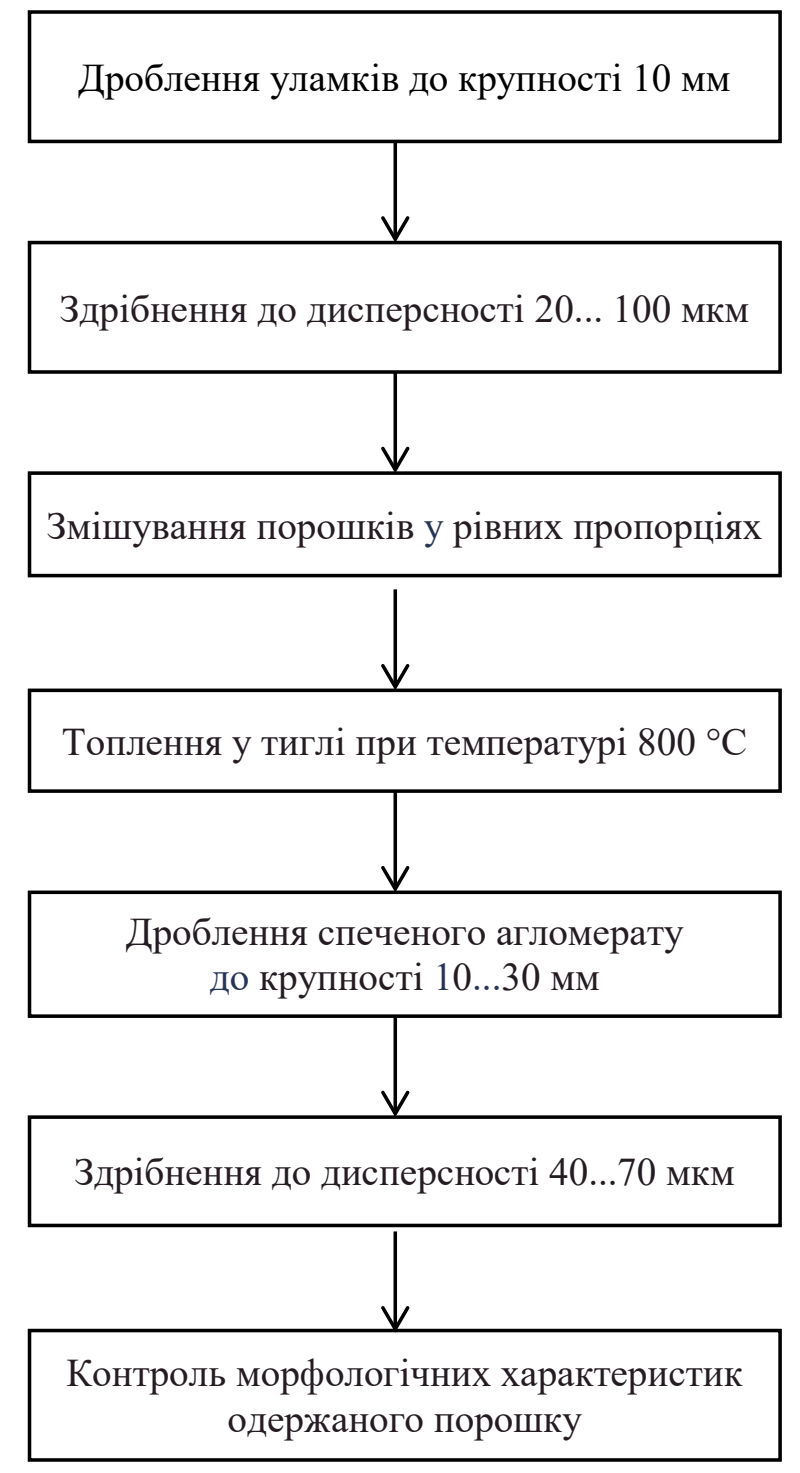

Рис. 1 Технологічна схема переробки бою скла та бракованих кришталевих виробів на склопорошок

Технологічні операції, режими, обладнання і пристосування

Таблиця 1

\begin{tabular}{|l|l|l|}
\hline \multicolumn{1}{|c|}{ Технологічні операції } & \multicolumn{1}{|c|}{ Обладнання і пристосування } & \multicolumn{1}{|c|}{ Режими } \\
\hline Дроблення & Дробарка механічна & Вільні \\
\hline Здрібнення & Кульовий млин барабанного типу & $\begin{array}{l}\text { Частота обертання ротора - 800 об/хв; } \\
\text { час розмелу - 20 хв/100 г скла }\end{array}$ \\
\hline $\begin{array}{l}\text { Топлення } \\
\text { порошкової суміші }\end{array}$ & $\begin{array}{l}\text { Установка для виготовлення } \\
\text { порошкових виробів [10] } \\
\text { Тигель 3 термічно необробленого } \\
\text { графіту марки МПГ-6 }\end{array}$ & $\begin{array}{l}\text { Швидкість підйому температури }-20 / \text { хв; iзотер- } \\
\text { мічна витримка при температурах } 300 ~ \\
\text { протягом } 800{ }^{\circ} \mathrm{C}\end{array}$ \\
\hline
\end{tabular}


Рентеноструктурний аналіз, виконаний на установці ДРОН-3, показав загальну рентгеноаморфність дослідного скла. Густину вимірено методом гідростатичного зважування. Приблизний хімічний склад застосованого для виготовлення порошку скла (табл. 2) визначено за допомогою мікрорентгеноспекрального аналізу (МРСА) 3 використанням електронного мікроскопа-мікроаналізатора РЭММА-102-02. Зйомку спектрограм здійснено з вирізаних фрагментів, на які для утворення електричного контакту з використанням установки ВУП5 (Вакуумний універсальний пост) нанесено тонкий ( $\approx 1-2$ мкм) шар алюмінієвого покриття. Результати досліджень показали наявність характерних спектрів $\mathrm{Si}, \mathrm{Na}$, $\mathrm{Ca}, \mathrm{K}, \mathrm{Pb}$, які дозволяють віднести дослідні зразки до подвійних та потрійних систем $\mathrm{PbO}-\mathrm{SiO}_{2}$, $\mathrm{Na}_{2} \mathrm{O}-\mathrm{CaO}-\mathrm{SiO}_{2}, \mathrm{Na}_{2} \mathrm{O}-\mathrm{SiO}_{2}$ [11]. Наявність у зразках 2 і 3 спектрів $\mathrm{Fe}, \mathrm{Ti}, \mathrm{Cr}$ пояснюється різними кольоровими відтінками застосованих виробів.

Детально розглянемо особливості та фізикохімічні процеси на кожному технологічному етапі (рис. 1). Закономірності виявлено за допомогою методів оптичної (мікроскоп БИОЛАМ-И) і електронної мікроскопії (електронний мікроскопмікроаналізатор РЭММА-102-02), підгрунтям для чого $є$ положення хімії твердого тіла та склоподібного стану [13-15].

Переробка скляного бою та бракованих кришталевих виробів починається 3 дроблення за допомогою дробарки до крупності близько 10 мм. Одержані уламки зазнавали сухого розмелу у кульовому млині барабанного типу. Як молольні тіла застосовано керамічні кульки, частота обертання ротора - 800 об/хв; час розмелу склав 20 хв на кожні 100 г скла. Введення операції здрібнення до дисперсності 20...100 мкм сприятиме інтенсифікації процесів силікато- та стеклоутворення під час термічного оброблення на наступному етапі. Здрібнені частинки мають уламкову форму. Проте, як показав досвід, викладений у роботі [12], недоліком застосування порошків, одержаних сухим розмелом, у високотемпературних технологіях, таких як електродугове напилення, $\epsilon$ низький коефіцієнт використання матеріалу
$(0,6 \ldots 0,7)$ внаслідок втрат дисперсного пилу. Крім того, скляні частинки зберігають свою так звану «історію» виготовлення виробу, тому у технологічному процесі введено етап топлення, який забезпечує вирівнювання хімічного складу під час змішування різних видів скла. Виходячи 3 того, що результати МРСА показали схожість дослідних зразків за хімічним складом, суміш виготовлено у рівних пропорціях; дозування порошків здійснено об'ємним способом.

Температурні режими термічного оброблення, під час якого виготовлена суміш топиться, перетворюючись на агломерат, обрано на основі аналізу діаграм стану $\mathrm{PbO}-\mathrm{SiO}_{2}, \mathrm{Na}_{2} \mathrm{O}-\mathrm{CaO}-\mathrm{SiO}_{2}$, $\mathrm{Na}_{2} \mathrm{O}-\mathrm{SiO}_{2}$ [11]. Процес розм'якшення досліджено за усадочними процесами, для чого застосовано авторський зразок лабораторної установки для виготовлення порошкових виробів [10], яка дозволяє щохвилинно вимірювати деформації сумішей під час термічних операцій. Для топлення скляного порошку застосовано графітовий тигель 3 термічно необробленого графіту марки МПГ-6 (ТУ 48-480729700), який запобігає прилипанню скла до бокових поверхонь. На думку автора роботи [16] дрібнозернистий графітовий пил $є$ активним відновником кремнезему, який сприяє прискоренню утворення центрів кристалізації $\mathrm{SiO}_{2}$; при температурі вище ніж $300{ }^{\circ} \mathrm{C}$ графіт окислюється та вступає в реакцію 3 повітрям, що знаходиться у порах формувальної суміші: таким чином, процес топлення відбувається у атмосфері СО. Головним елементом лабораторної установки [10] є піч вертикального завантаження з номінальною температурою $900{ }^{\circ} \mathrm{C}$ та окисною атмосферою. Кришка печі має знімну конструкцію: для проведення експериментальних досліджень замість неї встановлюється термостійке скло, скрізь яке можна спостерігати за процесами розм'якшення та склоутворення. В середину скляної суміші вставлена термопара градуювання ХА (ДСТУ 2837-94, ГОСТ 3044-94), що забезпечує контрольну точність вимірювання на двох етапах ізотермічної витримки відповідно при температуpax $300^{\circ} \mathrm{C}$ i $800{ }^{\circ} \mathrm{C}$. На першому етапі відбувається агломерація склопорошків, як це показано на фотознімку (рис. 1).

Таблиця 2

Результати досліджень зразків скла

\begin{tabular}{|c|l|l|l|c|}
\hline $\begin{array}{c}\text { № дослідного } \\
\text { зразку }\end{array}$ & \multicolumn{1}{|c|}{ Виріб } & \multicolumn{1}{|c|}{ Колір } & \multicolumn{1}{|c|}{ Наявність спектрів } & Густина, $\rho$ кг/м³ \\
\hline 1 & Фужери & Білий прозорий & $\mathrm{Si}, \mathrm{Na}, \mathrm{Ca}, \mathrm{K}, \mathrm{Pb}$ & 2800 \\
\hline 2 & Попільниця & Блідно-жовтий прозорий & $\mathrm{Si}, \mathrm{Na}, \mathrm{Pb}, \mathrm{Fe}$ & 3032 \\
\hline 3 & Ваза & Блідно-голубий матовий & $\mathrm{Si}, \mathrm{Na}, \mathrm{Pb}, \mathrm{Ti}, \mathrm{Cr}$ & 3000 \\
\hline
\end{tabular}




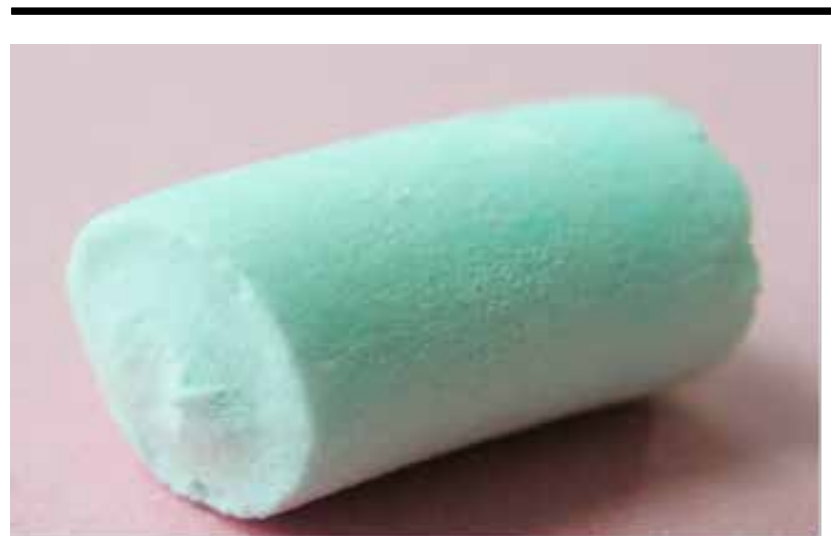

Рис. 2. Зовнішній вигляд експериментального зразку після термічного оброблення при $\mathrm{t}=300{ }^{\circ} \mathrm{C}$

Інтенсивність спікання склопорошків проаналізована за графічною інтерпретацією результатів досліджень усадочних процесів у напівлогарифмічних координатах, для чого авторами розроблено програмний розрахунковий комплекс на мові програмування Common Lisp [17]. Як видно з рис. 3 , при виході на режим $300 \ldots 800{ }^{\circ} \mathrm{C}$ перші 8-10 хв є найбільш ефективними для спікання дослідних порошків. При підвищенні температури до $800 \ldots 900{ }^{\circ} \mathrm{C}$ у межах цих систем відбувається процес силікатоутворення [5].

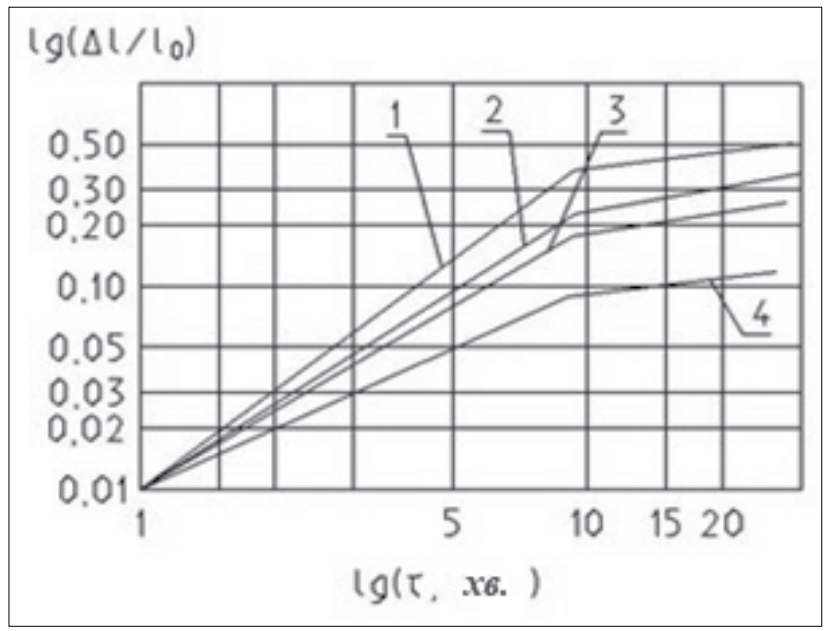

Рис. 3. Кінетика спікання скляних порошків різної дисперсності при виході на режим $800{ }^{\circ} \mathrm{C}$ : $1-10 . .30$ мкм; $2-30 . .60$ мкм; $3-60 . .90$ мкм; $4-\geq 100$ мкм

Закінчення усадки свідчить про завершення процесу формування компактного матеріалу, який має пузирчасту структуру (рис. 4), що, на думку авторів роботи [17], є суттєвим недоліком тигельної плавки. Проте для подальшої переробки на порошок це не впливає. Спечений агломерат певної форми можна застосовувати як сировину для тривалого зберігання або дробити та здрібнювати до дисперсності 40...70 мкм. Для поліпшення гранулоутворення під час здрібнення у кульових млинах додано полівініловий спирт (ГОСТ 10779-78).

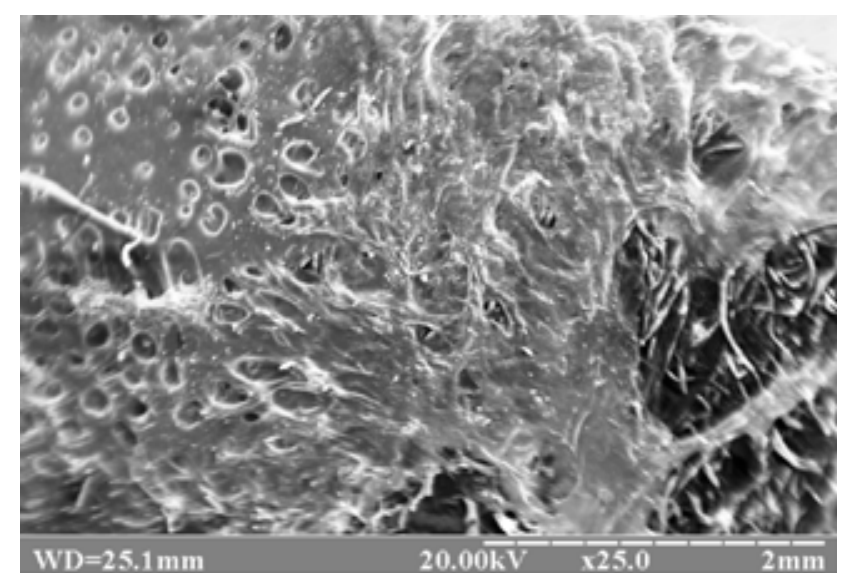

Рис. 4. Мікроструктура розтопленої у графітовому тиглі при температурі $800{ }^{\circ} \mathrm{C}$ скляної порошкової шихти

Одержані результати опосередковано збігаються 3 дослідженнями авторів робіт [7; 18-20], присвячених фізико-хімічним процесам створення нових легкоплавких стекол зі спеціальними властивостями.

Контроль морфологічних характеристик склопорошків досліджено методами оптичної і комп'ютерної металографії: оптичну мікрофотографію, наведено на рис. 5. Як показали результати рентгеноструктурного аналізу, одержані порошки $\epsilon$ рентгеноаморфними, мають середній розмір 50 мкм, за формою наближаються до сферичної. Ïх насипна щільність складає $300 \mathrm{\kappa r} / \mathrm{M}^{3}$; мікротвердість, яку виміряно на приладі ПМТ-3 (навантаження на індентор - 200 г), становить 1,4 ГПа.

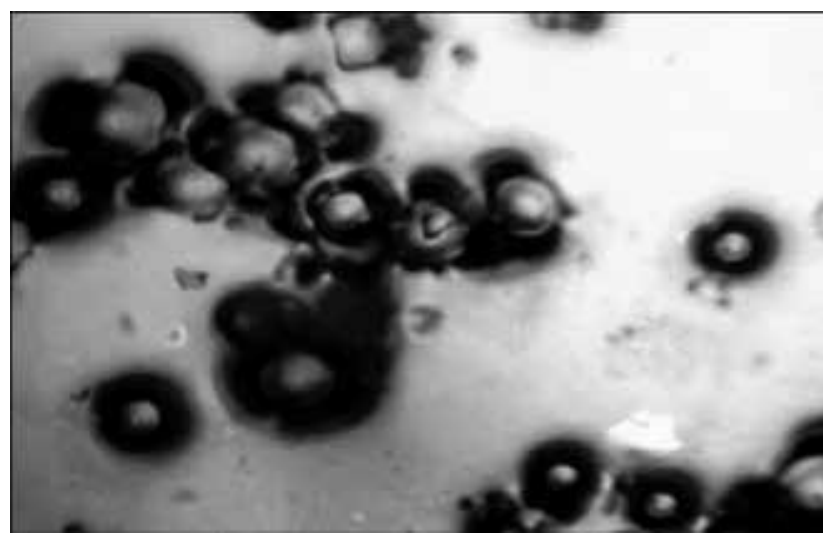

Рис. 5. Оптична мікрофотографія (×370) одержаного порошку 
Результати роботи поглиблюють наукові уявлення про фізико-хімічні процеси одержання склопорошків з кришталевих виробів, що спрямовано на вирішення актуальної на цей час науково-практичної проблеми переробки скляного бою та бракованих скляних виробів. Порівняно висока вартість вихідних матеріалів і технологічного процесу створює передумови для одержання стратегічно важливої сировини для функціональних композиційних матеріалів зі стабільними експлуатаційними властивостями. Перспективи подальших робіт пов'язано $з$ експериментальними дослідженнями фізико-хімічних властивостей одержаних порошків, зокрема у екстремальних умовах.

\section{Висновки}

1. Запропоновано технологічну схему одержання порошку шляхом переробки скляного бою кришталевого скла, яка включатиме у себе дроблення на дробарці до крупності до 10 мм 3 подальшим здрібненням до дисперсності $30 \ldots 80$ мкм у кульовому млині барабанного типу, виготовлення порошкової суміші з наступним іiі топленням при температурі $800{ }^{\circ} \mathrm{C}$ у муфельній печі з окиснювальним середовищем, дробленням та здрібненням спеченого агломерату.

2. Досліджено технологічні особливості i фізико-хімічні процеси, які відбуваються на етапах здрібнення і спікання порошкової суміші за визначеною схемою. Експериментально визначена і теоретично обгрунтована важливість процесу топлення скляного агломерату в діапазоні температур $300 \ldots 800{ }^{\circ} \mathrm{C}$ з максимальною інтенсивністю у перші $8-10$ хв.

3. Одержані порошки є рентгеноаморфними, мають округлу форму; їх гранулометричний склад належить діапазону $40 \ldots 70$ мкм.

\section{Список літератури:}

1. Куколев Г.В. Химия кремния и физическая химия силикатов : Учебник для вузов по специальности «Технология силикатов». Изд-во «Высшая школа». 1966. 462 с.

2. Маневич В.Е., Субботин К.Ю., Ефременков В.В. Сырьевые материалы, шихта и стекловарение : монография. : Стройматериалы. 2008. 223 с.

3. Пшінько О.М., Щербак А.С. Ефективний теплоізоляційний матеріал з відходів скляної промисловості. Мосты и тоннели: теория, исследования, практика. 2012. №1. С. 67-70.

4. Завгородня Н.I. Дослідження процесу утилізації екранного бою у виробництві керамічної плитки. ScienceRise. 2016. № 1/2 (18). C. 32-36.

5. Павлушкин Н.М. Стекло : справочник / под ред. Н.М. Павлушкина. Москва : Стройиздат. 1976. С. 324-345.

6. Терещенко И.М., Кравчук А.П., Стецкевич А.Ю. Разработка составов накладного стекла для изделий из хрусталя и их промышленная апробация. Труды БГТУ. 2014. № 3. С. 67-70.

7. Жерновая Н.Ф., Бессметрный В.С., Дорохов Е.С., Жерновой Ф.Е. Разработка и исследование специальных стекол для посуды. Вестник БГТУ им. В. Г. Шухова. 2015. № 1. С. 164-168.

8. Гулоян Ю.А. Декоративная обработка стекла и стеклоизделий. Москва : Высшая школа. 1989. 223 с.

9. Гришина А.И. Химические технологии в науке и их роль. Наука и техника Казахстана. 2018. № 3. C. 82-86.

10. Установка для виготовлення порошкових виробів : пат. 99331 Україна, МПК В22F3/14. № 201414197 ; заявл. 30.12.2014 ; опубл. 25.05.2015, Бюл. № 10.5 c.

11. Торопов Н.А., Борзаковский В.П., Лапин В.В. Диаграммы состояния силикатных систем : справочник. Вып. 1. Двойные диаграммы. Москва ; Ленинград : Наука. 1965. 545 с.

12. Казимиренко Ю.О. Порошки систем $\mathrm{Na}_{2} \mathrm{O}-\mathrm{CaO}-\mathrm{SiO}_{2}$ i $\mathrm{K}_{2} \mathrm{O}-\mathrm{PbO}-\mathrm{SiO}_{2}$ : переробка відходів і процеси розм’якшення. East European Scientific Journal Wschodnioeuropejskie Czasopismo Naukowe. 2018. № 7 (35), vol. 2. P. 21-30.

13. Даувальтер А. Хрустальные, цветные и опаловые стекла. Москва : Гизлегпром. 1957. 235 с.

14. Анфилогов В.Н., Быков В.Н., Осипов А.А. Силикатные расплавы : монография. Москва : Наука. 2005. $357 \mathrm{c}$.

15. Аппен А.А. Химия стекла. Ленинград : Химия, 1974. 352 с.

16. Бачин В.А. Диффузионная сварка стекла и керамики с металлами. Москва : Машиностроение. 1986. 184 с.

17. Сайбеот П. Практическое использование Commtn Lisp: пер. с англ. Москва : ДМК-Пресс. 2017. $488 \mathrm{c}$.

18. Корякова 3., Битт В. Легкоплавкие стекла с определенным комплексом физико-механических свойств. Компоненты и технологии. 2004. № 4. С. 126-128.

19. Гловин Н.М. Дослідження фізико-механічних властивостей скла в залежності від його складу і ступеня обробки. Фізика і хімія твердого тіла. Т. 14. № 1(2013). С. 145-148.

20. Шапилова, М.В., Акимова С.И. Экологические проблемы в производстве сортовых стекол и хрусталя. Стекло мира. № 4. С. 81-82. 
Kazymyrenko Yu.O., Drozd O.V., Zharskiy Ye.V. TECHNOLOGICAL FEATURES

AND PHYSICOCHEMICAL PROCESSES OF PROCESSING

\section{OF CRYSTAL GLASSES TO POWDER}

The article is devoted to solving the current scientific and practical problem of processing glassware and defective glassware made of sodium silicate glass, types of crystal, sodium-calcium-silicate glass, which saturate the modern market. A perspective area of chemical technology is the production of glass powders. The authors propose a technological scheme for processing glass and defective crystal products into glass powder. Experimental works and laboratory researches on definition of chemical composition, structure, properties have been described. Methods of optical and electron microscopy, X-ray diffraction analysis; analytical calculations of the kinetics of high-temperature processes have been used. The obtained results are compared with the state diagrams $\mathrm{PbO}-\mathrm{SiO}_{2}, \mathrm{Na}_{2} \mathrm{O}-\mathrm{CaO}-\mathrm{SiO}_{2}, \mathrm{Na}_{2} \mathrm{O}-\mathrm{SiO}_{2}$. The softening process has been investigated by shrinkage processes, for which an author's sample of a laboratory installation for the manufacture of powder products has been used.

The authors propose a technological scheme for processing glass and defective crystal products into glass powder, which will include crushing operations on a crusher to a size of $10 \mathrm{~mm}$ with subsequent grinding to a dispersion of $30 \ldots 80 \mu \mathrm{m}$ in a drum-type ball mill, making a powder mixture followed by melting at a temperature of $800^{\circ} \mathrm{C}$ in a muffle furnace with oxidizing medium, crushing and grinding of sintered sinter. It was found that the obtained powders are X-ray amorphous, have a rounded shape; their particle size distribution belongs to the range of $40 \ldots 70 \mu \mathrm{m}$, their microhardness is about $1.4 \mathrm{GPa}$. Physicochemical processes characteristic of each of the stages of the technological cycle are analyzed. Theoretical substantiation of temperature regimes and results of microstructural researches, morphological characteristics of the received powders are given. The importance of the glass agglomerate melting process in the temperature range of $300 \ldots 800^{\circ} \mathrm{C}$ with the maximum intensity in the first $8-10$ minutes has been experimentally determined and theoretically substantiated. Prospects for their further application for the manufacture of new functional composite materials and coatings with stable performance properties have been proposed.

Key words: processing, technology, crystal glass, glass battle, defective glass, glass powder, physicochemical processes. 